\title{
4 Political Activism, Organisation and Change in the Late Colonial Copperbelt
}

\section{Introduction}

This chapter provides a social history of African labour and political organisation on the Central African Copperbelt between World War Two and the independence of the Democratic Republic of Congo in 1960 and Zambia in 1964. While Africa's decolonisation has been well documented by political scientists and political historians, it has often been presented in what Cooper has criticised as a teleological manner, working backwards from independence to explain inexorable progress towards it, in terms of the actions of European states and African nationalists. ${ }^{1}$ The specificities of associational life in late colonial Africa have often been drowned out by the beating clock of a hegemonic nationalism, against which all other forms of 'sectional' activism are treated as secondary.

This chapter does not provide a history of political institutions or individual leaders and does not assess the specific contribution of Copperbelt residents and their organisations to the achievement of independence. ${ }^{2}$ Instead, it explores how their ideas about political and social advancement intersected with the limited organisational

1 Cooper, Decolonization and African Society, pp. 6-9.

2 Many such studies are available. For Zambia see Rotberg, The Rise of Nationalism in Central Africa and the latter sections of both Richard Hall, Zambia, 1890-1964: The Colonial Period (London: Longman, 1976) and Andrew Roberts, A History of Zambia (London: Heinemann, 1976). For a later post-nationalist interpretation, see Jan-Bart Gewald, Marja Hinfelaar and Giacomo Macola (eds.), One Zambia, Many Histories: Toward a History of Post-Colonial Zambia (Leiden, Brill, 2008) and Gewald et al., Living the End of Empire. For Congo/Katanga see Crawford Young, Politics in the Congo: Decolonization and Independence (Princeton, NJ: Princeton University Press, 1965); Lemarchand, Political Awakening in the Congo; and, from a more social perspective, Georges Nzongola-Ntajala, The Congo from Leopold to Kabila: A People's History (London: Zed Books, 2002), especially pp. 61-93. 
forms - labour unions, welfare associations, ethnic associations and, only belatedly, political parties - available to them. While these ideas and movements sometimes coincided with and contributed to the achievement of independence, this was not usually their primary goal. ${ }^{3}$

The economically strategic Copperbelt mining industry was at the heart of each countries' decolonisation: exploitation of the region's globally significant mineral resources informed both colonial powers' desire to retain them and nationalist plans for their developmental transformation. However, the region's role in the two neighbours' struggles for independence provides a striking contrast. The Northern Rhodesian Copperbelt was in the 1950s the vanguard of the territory's anti-colonial movement: nationalist parties regarded organised labour and the mineworkers' union in particular as a powerful mass movement that, with its ability to paralyse the economy, could help loosen Britain's colonial grip. The urban social consciousness identified by RLI researchers informed how the labour movement was understood and characterised itself, marginalising 'rural' and 'ethnic' customs and identities in favour of a 'modern' materialist political consciousness. Despite disagreements and conflicts, Zambia's nationalist movement proved relatively unified and successful. Haut-Katanga's political leadership was far more divided: while the mining towns' multi-ethnic workforce was channelled into paternalistic participation in Indigenous Enterprise Councils (CIEs), the educated elites who joined the Catholic missions' cultural cercles were recognised as legitimately modern, yet given no meaningful political power. In Congo's chaotic rush to independence in 1959-60, an aspirant 'migrant' educated elite clashed with rural, 'autochthonous' leaders and their urban allies in ethnic associations, leading to both the Katangese secession and the violence experienced during it.

There are important structural explanations for these different outcomes, including the contrasting and changing metropolitan policies regarding decolonisation of these territories. While racial segregation in Northern Rhodesia, reflecting its integration into the settler-led Central African Federation in 1953, encouraged multi-ethnic unity and direct action, the outright ban in Belgian Congo on territorywide African political organisations fuelled the expression of political aspirations via ethnic associations. However, these differences also

3 Thomas Hodgkin, Nationalism in Colonial Africa (London: Frederick Muller, 1956). 
reflected the unfolding social history of the Copperbelt and the knowledge production process that was central to it. Policy responses to wartime labour unrest shaped the political institutions within which African mineworkers and their communities articulated their grievances and advanced their aspirations to a better life. Analysts assessed the role of these institutions and their leaders according to the extent to which they demonstrated a transition to modern norms. 'Elite' Africans sought to demonstrate their readiness for modern 'citizenship' but were prevented from taking up a junior position in the colonial administration, thereby encouraging an uneasy alliance with the urban masses from whom they otherwise sought to differentiate themselves.

Ethnic associations flourished on both sides of the Copperbelt border in the 1950s, as urban migrants sought to secure a foothold in the town via kinship support networks, but only in Haut-Katanga did they become a primary vehicle of 'modern' political organisation. Today, it is widely appreciated that politicised ethnicity across sub-Saharan Africa is a modern phenomenon, not a direct reflection of either precolonial identities or the colonial reconstructions of it. ${ }^{4}$ Supposedly 'modern' political parties and unions were influenced by ethnic thinking and mobilisation, but Zambian Copperbelt elites understood, partly as a result of their interaction with Western(ised) intellectuals, that this was considered illegitimate and incompatible with modernity. In contrast, many Katangese urbanites sought advancement via ethnic associations that were equally as 'modern' and 'urban' as Zambian parties and unions, insofar that they were specifically created to respond to the challenges and uncertainties of town life.

\section{A Working Class in the Making?}

James Ferguson has recently problematised the use of the term 'proletarian' to describe the very un-proletarian (in historical terms) South African working class, to draw attention to analogous terminology in 'taken-for-granted' processes of knowledge production. ${ }^{5}$ Analogous

4 Bruce J. Berman, 'Ethnicity, Patronage and the African State: The Politics of Uncivil Nationalism', African Affairs, 97, 388 (1998), pp. 305-41; Lynch, I Say to You.

5 James Ferguson, 'Proletarian Politics Today: On the Perils and Possibilities of Historical Analogy', Comparative Studies in Society and History, 61, 1 (2019), pp. 4-22. 
thinking drawn from the West's modern history was hugely influential in how policy makers and academic observers understood Africa's experience of social and political change in the mid-twentieth century, shaping the representation of Africans in 'modern' political institutions. However, because this Western history was itself only partially understood, open to interpretation and wrongly presented as an idealised experience of enlightenment and modernisation, the analogous lessons that were drawn varied substantially. Virtually all observers of social change in the late colonial Copperbelt assumed that existing forms of indigenous power, essentially chiefly authority, would be an inadequate or inappropriate basis for political legitimacy in this new urban milieu. Their ability to assess the pace and degree of political change, or to identify more suitable forms of political authority, was, however, powerfully shaped by a modernist mode of thought that counterposed rural communitarianism to urban individualism and equated Western institutions with modernisation.

As we saw in Chapter 1, Northern Rhodesian mine labour was widely characterised - by policy makers and in contemporary academic studies as an incipient 'working class in the making' that represented a threat not only to company profitability but ultimately to colonial control. Protests about specific grievances, for example over wages or conditions, were therefore interpreted as manifestations of this threat. Take, for example, the riots and strike action in May 1935 in the mining towns of Northern Rhodesia, prompted by a tax increase. The inquiry into these events concluded that the tax rise had been badly communicated, but also found that, at Luanshya, 'the elders of the mine compound, and also other responsible natives' had assured managers that 'no disturbances could possibly happen there'. ${ }^{6}$ This breakdown of 'traditional' authority was found to have contributed to a deterioration into violence in which the police opened fire, killing six and injuring two dozen workers. The inquiry report therefore focussed on whether new 'modern' forms of liaison were needed to replace the system of elders.

Initially, the mines adopted a more elaborate system in which older men, specifically selected for their patriarchal authority and expertise in specific 'tribal' customs, were appointed to the position of Tribal Representative. Morris Chimfutumba grew up in the Mufulira home of his brother-in-law, whose authority as a mine-company-appointed

6 Northern Rhodesia, ‘1935 Commission of Inquiry into Disturbances’, p. 22. 
'tribal headman' rested on these attributes. ${ }^{7}$ Such expertise was, however, found wanting in the larger strike of 1940, in which African workers sought both jobs reserved for whites and the same wage those whites received. Tribal Representatives were marginalised in a strike led by an ad hoc 'Committee of Seventeen': it was violently suppressed, with seventeen men being killed and dozens injured. ${ }^{8}$

In the Haut-Katanga mining industry, as we have seen, greater and earlier attention was paid to the stabilisation and training of its African workforce and the provision of housing and limited social services. This did not, however, prevent periodic industrial unrest. Higginson explains a wave of protests, absconding, sabotage and theft by UMHK workers in the late 1930 s and early 1940 s as a response to demands for greater productivity and - during World War Two - increased output. These culminated in the December 1941 mineworkers' strike, prompted by UMHK's failure to control inflation of food prices, but interpreted by Higginson as workers' expression of betrayal by the supposedly philanthropic company. ${ }^{9}$ In Jadotville (later Likasi), alongside workers' demand for a pay rise, the strike saw their wives demanding the restoration of company provision of sewing machines and cloth, and the distribution of ration tickets to themselves as well as their husbands. ${ }^{10}$ A subsequent planned revolt by African soldiers in 1943 failed when évolués of mostly Kasaian origin, a driving force behind the mutiny, failed to gain wider community support, heightening ethnic tensions. ${ }^{11}$ There was, however, little practical connection between the emergent indigenous elite and the grievances of UMHK mineworkers. ${ }^{12}$

\section{Post-War Political Reform and African 'Leadership'}

The Copperbelt authorities nonetheless understood these diverse revolts and strikes as a profound challenge to their authority. The prominent role in protests of independent African churches, particularly the

7 Morris Chimfutumba interview.

8 Epstein, Politics in an Urban African Community, pp. 62-5.

9 Higginson, Working-Class in the Making, pp. 181-3.

10 Higginson, Working-Class in the Making, pp. 189-90.

11 Bruce Fetter, 'The Luluabourg Revolt at Elisabethville', African Historical Studies, 2, 2 (1969), pp. 269-77.

12 Fetter indeed notes that of 118 educated Africans who planned the revolt, only one was employed by UMHK: 'Luluabourg Revolt', p. 272. 
Kitawala religious movement, raised the prospect that such religious sects would combine with worker revolts to fuel unstoppable anticolonial revolt. ${ }^{13}$ This reinforced a growing official view that the political consequences of urbanisation could no longer be avoided and that political modernisation was necessary to address them. Analogous thinking meant that variations of the tripartite co-operation then being pursued in post-World War Two western Europe, with state intervention to limit capitalist freedom and manage class conflict, were the way ahead. Colonists and companies in both Copperbelt regions accepted that company decisions had at least to be better communicated to African workers, necessitating new intermediary institutions. The specific institutional forms adopted were, however, also shaped by contrasting beliefs concerning the central question of African 'adaptability' to modernity, particularly among so-called advanced Africans.

In Haut-Katanga following the 1941 strike, the influential Benedictine leader Monsignor de Hemptinne opposed the introduction of trade unions because he believed even educated Africans were not currently capable of running 'modern' organisations:

The native who has a fairly well-developed education or professional knowledge generally does not have enough freedom of mind or social sense to free himself from tribal influences. Susceptibility, jealousy and personal concerns prevent black people from impartially fulfilling a social role outside their usual environment. ${ }^{14}$

This view was legitimised by CEPSI research. Doucy and Feldheim attributed African interest in unions to a mimicry of European mineworkers: ' $[t]$ he phenomenon of imitation must be taken into consideration because it is this, rather than a working consciousness, that drives certain natives to wish for a generalisation of unions'. ${ }^{15}$ They argued that establishing trade unions (as was briefly Belgian government

13 Karen E. Fields, Revival and Rebellion in Colonial Central Africa (Princeton, NJ: Princeton University Press, 1985); John Higginson, 'Liberating the Captives: Independent Watchtower as an Avatar of Colonial Revolt in Southern Africa and Katanga, 1908-1941', Journal of Social History, 26, 1 (1992), pp. 55-80; Nicole Eggers, 'Kitawala in the Congo: religion, politics and healing in 20th-21st century Central African History', unpublished PhD thesis, University of Wisconsin (2013).

14 Quoted in S. Mukala, Mémoire de licence en histoire, UNAZA, 1981; cited by Dibwe dia Mwembu, Histoire des Conditions de Vie, p. 42.

15 Doucy and Feldheim, Problems du Travail, p. 112. 
policy) before Africans possessed the consciousness required was damaging to the cause of labour. ${ }^{16}$ Although efforts were made to establish African unions in the immediate post-World War Two period, they could only operate under strict European supervision and were effectively excluded from UMHK's paternalistic system. ${ }^{17}$ Instead, alongside a massive expansion in spending on social welfare and family housing, legislation passed in 1946 compelled the company (and all other enterprises with 250 or more African workers) to establish Indigenous Enterprise Councils (CIEs): the UMHK CIE is analysed below.

In Northern Rhodesia, the best way to manage the threat of uncontrolled proletarianisation was widely debated. Many colonial and mine company officials, drawing on South African segregationist and migrant labour models, still sought to avoid permanent African urbanisation precisely because of the threat posed by a black proletariat. The Copperbelt Provincial Administrator argued that British policy must 'encourage the native to develop his own areas and his own form of government by gradually absorbing ideas of civilized government'. Urban society was 'a cancer that would destroy not only rural life but [also] the possibility of Africans finding their own way into the modern world'. ${ }^{18}$ Other officials believed that African adaptation to urbanisation could work if it was gradually and carefully controlled. Northern Rhodesia Governor Sir John Maybin argued that '[i]f Africans were stabilized in the urban society without an undue raising of their aspirations and capacities the economic conditions for a harmonious estate society would have been achieved'. ${ }^{19}$

More concretely, the 1940 strike was followed by the establishment the following year of an Urban Advisory Council, bringing together district commissioners with African appointees from both mine and municipal townships. This was reconstituted in 1949, with limited elections to select representatives from each section of urban society. Meanwhile an African Representative Council was established in 1946 to advise the Governor. These structures were dominated by

16 Doucy and Feldheim, Problems du Travail, p. 114.

17 Bogumil Jewsiewicki, 'La Contestation Sociale et la Naissance du Prolétariat au Zaïre au Cours de la Première Moitié du XXe Siècle', Canadian Journal of African Studies, 10, 1 (1976), pp. 47-71, p. 68; Nzongola-Ntajala, The Congo from Leopold to Kabila, pp. 73-6.

18 NAZ, SEC/NAT/92, 1 February 1940, quoted in Heisler, 'Creation of a Stabilized Urban Society', p. 134.

19 Quoted in Heisler, 'Creation of a Stabilized Urban Society', p. 133. 
'advanced' Africans and were not taken seriously as a representative body of African opinion. ${ }^{20}$ British company and colonial officials remained divided as to the best way to ensure effective advancement without political destabilisation, certainly compared with the relative cohesion of 'native policy' in urban Haut-Katanga overseen by the Catholic Church, mine company and state. ${ }^{21}$ It fell to metropolitan politicians to intervene decisively in Northern Rhodesian labour relations.

\section{AMWU and Its Analysts, 1947-1956}

The British government's decision to dispatch William Comrie of the Trade Union Congress to Northern Rhodesia to oversee the establishment of legal trade unions in 1947 reflected its hope that the political consequences of labour unrest could be addressed by institutional intervention. Comrie helped establish the African Mineworkers' Union (AMWU) in 1949 and an African Trade Union Congress in 1951. These bodies, British officials fondly believed, would negotiate rather than strike and act 'responsibly' in the interests not only of their members but also of wider society. By the early 1950s AMWU had established itself with an effective bureaucracy and able leaders, who became the subject of concern among colonial and company officials and of sympathetic attention from RLI researchers. As Epstein emphasised, 'by virtue of their education, their proficiency in English, and their more obvious approximation to European standards in dress and habit, they were ... the intermediaries between the mass of the African people and the European authorities'. ${ }^{22}$ As soon as AMWU secured recognition by the mine companies to negotiate over wage and workplace issues, it challenged the legitimacy of Tribal Representatives as a parallel form of dispute resolution. ${ }^{23}$ The Luanshya Labour Officer characterised its view thus:

20 Epstein, Politics in an African Community, pp. 71-2.

21 Guy Vanthemsche rightly warns that the degree of unanimity between this socalled 'triumvirate' has been overstated: Belgium and the Congo, 1885-1980 (Cambridge: Cambridge University Press, 2012), p. 71.

22 Epstein, Politics in an Urban African Community, p. xvi.

23 NAZ, LSS 1/26/33, Luanshya AMWU, 1949-65, Commissioner for Labour and Mines to Secretary for Native Affairs, 13 December 1949. 
while ... the Union recognises the necessity of the tribal loyalties and administration continuing in Rural areas for some time to come, they feel that the same necessities ... do not apply now in urban areas. They appear to feel that the time is perfectly ripe for what they called the urbanisation of populations on [the] Copperbelt.... there is a tendency to regard the Union as a potential and proper form of local or community government. ${ }^{24}$

While mine companies initially resisted the abolition of Tribal Representatives, AMWU's persistent campaigning on this issue led in 1953 to a referendum of mineworkers: with a turnout of 84.8 per cent of the mines' 35,000 -strong workforce, 96.9 per cent of those who voted supported abolition of the tribal representative system, ensuring that the union became the sole recognised organisation for African mineworkers. ${ }^{25}$

The potency of AMWU lay in the ability of its 'advanced' leadership to respond to and mobilise around the grievances of less educated mineworkers, most of whom (Chapter 2) did low-paid unskilled work. The AMWU leadership negotiated with mine managers over pay and conditions, but also held regular public meetings in mine townships, attended by thousands of mineworkers, their families and many non-members. ${ }^{26}$ Parpart records the prominence of women at such meetings; they helped shape union demands, not only for higher wages but also improved housing and other conditions of township life (see also Chapter 5). Branch officials challenged the dismissal of African workers following racial clashes between themselves and European supervisors, as well as other local management decisions. They also, Epstein shows, addressed community grievances arising from, for example, hospital visits and the arrest of women brewers. ${ }^{27}$ By such means AMWU became the dominant organisational force in township life. Official membership fluctuated wildly: in 1950, for example, the Luanshya branch had 8,700 members, of whom only 5,000 had union dues deducted from their pay. ${ }^{28}$ But the union was

NAZ, LSS 1/26/33, Luanshya AMWU, 1949-65, Labour Officer Luanshya to Commissioner for Labour and Mines, 18 February 1950.

25 The referendum is discussed in Epstein, Politics in an Urban African Community, p. 100.

26 Matthew Mwendapole, A History of the Trade Union Movement in Zambia up to 1968 (Lusaka: UNZA Institute for African Studies, 1968), pp. 30-1.

27 Epstein, Politics in an Urban African Community, pp. 124-5.

28 NAZ, MLSS 1/23/24, Annual Reports, Labour Officer, Luanshya, 1947-67, Labour Department Luanshya Annual Report 1950. 
generally able to mobilise the township population to support its actions, for example through mass picketing. ${ }^{29}$ The major 1952 strike over a pay rise was sustained by women's farmed produce following the withdrawal of company rations. ${ }^{30}$

The enthusiastic adoption of trade unionism among these mineworkers - and other workers in the 1950s - convinced analysts such as Epstein that advanced Africans could participate successfully in modern political structures. The union's officials, mostly clerks and the few more senior African skilled manual workers, were expected to provide a moderating and responsible leadership that would persuade members to accept the 'realities' of wage labour in a 'modern' workplace. Certainly, AMWU's senior leaders, notably its first president Lawrence Katilungu (1949-61), sometimes distanced themselves from their members' actions with the discourse of responsible leadership. In 1956, for example, Katilungu condemned an outbreak of unofficial strike action: 'the union, he said, controlled a very complex group of people, some of whose education and civilisation was low'. ${ }^{31}$ In negotiations, AMWU leaders characterised their members' demands as reflecting their progress as morally upright workers, progress that could be most effectively ensured by improved wages and conditions. ${ }^{32}$ Such demands were framed by the notion of a stable and respectable family life in town, characterised by the steady conversion of 'wants' into 'needs'. ${ }^{33}$ But AMWU's elite leaders also maintained their focus on poorer members: in 1952 they rejected a pay formula that did not increase wages for the vast majority of employees on Grades 1 to 3 and insisted on a flat-rate increase. ${ }^{34}$ This frustrated company attempts to incentivise productivity among skilled workers. While companies, policy makers and later African nationalists emphasised the 'advancement' of Africans into skilled

33 Parpart, 'The Household and the Mine Shaft', pp. 42-3.

34 Epstein, Politics in an Urban African Community, p. 97. 
jobs previously done by whites, AMWU recognised that this was less important to most members than generalised pay increases and improvements to housing and social provision. Epstein nicely captures the tension between unity and differentiation in the heterogeneous mine township (see also Chapter 3):

it is no longer possible to view the population of an African Mine Township as an undifferentiated mass. It includes the casual labourer and the relatively skilled worker; the migrant labourer and the urban dweller who was born and brought up in the towns; the illiterate and the highly sophisticated, and so forth. The population of the Township is held together by common interests created in the joint productive task, and its unity is expressed politically by the local branch of the Union. But since the population is also divided by cleavages ... these cleavages too must find their expression within the Union. ${ }^{35}$

Largely absent from Epstein's analysis is, however, the role of ethnicity within AMWU. The uneven provision of mission education in rural southern Africa meant that most clerks and other literate mineworkers were of Lozi and Nyasa origin, while the largest group of unskilled workers were Bemba speakers. This had the potential of dividing mineworkers and their union along intersecting class and ethnic lines. An uneasy unity found expression in AMWU's leaders: alongside many white-collar workers of non-Bemba ancestry, President Katilungu was a Bemba with aristocratic credentials. The continued colour bar, frustrating the promotion of skilled Africans to senior positions reserved for whites, certainly helped ensure African unity. But the downplaying of ethnic difference should also be understood as a consciously political position that found its way into research findings. Schumaker notes that, while RLI research assistant Simon Katilungu found evidence of 'tribal feelings' among Copperbelt Africans, he instead emphasised the importance of 'black nationalism' in their interactions with whites, reflecting the supposed diminishing of 'tribal' identities. ${ }^{36}$ Epstein, while accepting that ethnic differences had been significant in the recent past, stressed that in Luanshya 'people of many tribes are intermingled,

35 Epstein, Politics in an Urban African Community, p. 128.

36 S. C. Katilungu, 'A Study of Relations between Northern Rhodesia African Mine Workers Trade Union, and Mine Compounds Tribal Representatives and Copperbelt Mine Managers', p. 11, Mitchell Papers, cited in Schumaker, Africanizing Anthropology, p. 213. 
and new bonds of co-operation based on propinquity and neighbourliness are constantly being formed'. ${ }^{37}$

The union also asserted its right to negotiate over community as well as workplace issues, something that was strongly resisted by the mine companies, which insisted on a narrower and more conventional company-union relationship. The Chamber of Mines proposed new African mine township advisory committees but resisted AMWU calls for these bodies to be elected: 'The Companies were loath to establish African Mine Township Boards because they felt that any elected representation would inevitably be by members of the Union. ${ }^{38}$ The Boards that were ultimately established were composed entirely of appointed representatives, with AMWU restricted to just two members. As it became clear that AMWU was not playing the moderating role envisaged for it by British policy makers, the companies divided off white-collar workers into a separate Mines African Staff Association (MASA), both to weaken AMWU and to enable the aspirations of more educated and skilled workers to be expressed separately. ${ }^{39}$

The linked issues of union authority, advancement, productivity and representation came to a head in 1955 following a ballot in which 18,110 participants voted in favour of strike action and 365 against. ${ }^{40}$ The resultant strike was reinforced by mass township meetings attended by up to ten thousand men, women and children. At these meetings prayers were said and dance groups performed. Union representatives condemned strikebreakers, termed 'makobo' or tasteless fish, insisting that if striking workers were evicted from the townships they could build their own huts and draw water from mine Mufulira stream. ${ }^{41}$ The union's demand for a general wage increase was rejected by the companies, which insisted that all new pay rises must be linked to productivity improvements. The AMWU representatives articulated

Epstein, Politics in an Urban African Community, p. 9.

NAZ, WP 1/5/9, African Mine Townships Nkana, 1954-9, Commissioner for Labour C. E. Cousins to Secretary of Native Affairs, 3 June 1954.

39 Parpart, Labour and Capital, pp. 140-7.

40 For a summary of strike events, see Henry S. Meebelo, African Proletarians and Colonial Capitalism: The Origins, Growth and Struggles of the Zambian Labour Movement to 1964 (Lusaka: Kenneth Kaunda Foundation, 1986), pp. 287-96.

41 ZCCM-IH, 10.1.8F, African Labour - Trade Union, 1955-6, Reports of Mufulira AMWU Meeting, 25 January 1955 and Roan AMWU Meeting, 28 January 1955; Mwendapole, History of the Trade Union Movement, p. 25. 
their demands in aspirational terms, explaining that mineworkers' urban existence necessitated consumer goods and modern facilities including household electricity:

Mr Namitengo said that ... African employees were unable to provide the essential articles of furniture which they required. There was also the expenditure which the African incurred for candles and paraffin for lighting purposes because their houses were not supplied with electricity. Mr Puta said that through the efforts of the Welfare Departments the wives of employees were learning to sew and make clothing ... and this led to demands for sewing machines which they could not afford. Their wives and children were also acquiring a higher standard of living.... It was in the future interests of the Companies that the present children were brought up properly. ${ }^{42}$

Meanwhile, AMWU sought to restrict MASA's membership to supervisory staff while retaining the clerks who composed much of its senior leadership. Lengthy negotiations over which categories of workers should be represented by each body centred ultimately on conflicting definitions of the union's role. For AMWU General Secretary Matthew Nkoloma, theirs was 'an industrial Union which catered for everybody in the industry, including such employees as Hospital and clerical staff. The Companies were trying to split up the African community into two classes'. ${ }^{43}$ The private advice of the Chamber's industrial relations advisor demonstrated the limited extent to which mine companies had accepted the legitimacy of African unions, compared unfavourably with their Western counterparts:

Trade unionism for Africans has been tried, and has failed. It was artificially created and is rotten to the core. The strong and sound unions in more advanced countries were built up, slowly and laboriously ... by men of firm purpose and, in the main, integrity.... Here the leaders are, at the least, lacking in intelligence and experience, and the mass of workers is but little removed from primitive savagery. ${ }^{44}$

Colonial district officers held similar views:

42 ZCCM-IH, 10.1.8F, African Labour - Trade Union, 1955-6, Chamber Executive Committee, 8th Meeting with NRAMWU, 19 August 1955, p. 4.

43 ZCCM-IH, 10.1.8F, African Labour - Trade Union, 1955-6, 8th Meeting with NRAMWU, 19 August 1955, p. 6.

44 ZCCM-IH, 10.1.8F, African Labour - Trade Union, 1955-6, Memo, Industrial Relations Advisor to Chamber of Mines, 24 November 1955. 
from what I have seen at Bancroft and at Chingola ... Militant Trade Unionism, which did so much for working conditions at home before the 1914 war, is not suited to this time and place. It is simply the duty of Government to see that justice is done between Employer and Servant. ${ }^{45}$

Such views underpinned the hardline stance of the companies, which in January 1955 temporarily dismissed all striking mineworkers and only reversed this decision when the Governor of Northern Rhodesia, concerned about the unrest (and metropolitan political criticism) that would follow the eviction of tens of thousands of mineworkers and their families, applied pressure for leniency. ${ }^{46}$ The relative failure of the 1955 strike, and the preventative rural detention of many AMWU leaders following the state of emergency invoked following industrial action in 1956, certainly weakened the union. ${ }^{47}$ In the late 1950 s, in a context of economic recession (see Chapter 2), the frustration of AMWU demands caused many mineworkers to turn to the increasingly militant campaign for self-government to address their aspirations.

\section{UMHK's Indigenous Enterprise Council (CIE), 1947-1958}

The Indigenous Enterprise Council (CIE) of UMHK was established in 1947 and met sixty-eight times in the period before independence in 1960. It was the main institutional link between the workforce and the company. It has not been possible to obtain the minutes of its meetings, so we must rely on UMHK reports of its activities, as well as the recollections of mine township residents. ${ }^{48}$ The CIE members were (s)elected for two-year terms; in contrast to AMWU, its councillors were elected to represent and address both workplace and township concerns. The company claimed that CIE members were 'appointed by the workers after consulting as many of them as possible and ensuring fair representation of the various departments'. ${ }^{49}$ The CIE candidates were likely to be longstanding mineworkers who were well-respected and skilled, that is, senior in either 'ethnic' or 'modern'

45 NAZ, WP, 1/2/18, Tour Reports Mine Districts, 1951-5, Tour Report no. 1 of 1954, Chingola District, 4 October 1954, DO R. J. Shaw.

46 ZCCM-IH, 10.1.8F, African Labour - Trade Union, 1955-6, 7th Executive Committee Meeting, 31 January 1955.

47 Meebelo, African Proletarians and Colonial Capitalism, pp. 310-27.

48 Dibwe dia Mwembu, Histoire des Conditions de Vie, pp. 51-3.

49 UMHKA, 658, MOI Annual Report 1958, p. 47. 
terms. These were identified by both company and community representatives and, as Dibwe dia Mwembu argues, they were also chosen on the basis of their docility vis-à-vis company authority. ${ }^{50}$

Underlying the CIE was then an assumption similar to that at work in the very different context in Northern Rhodesia: an advanced and experienced set of representatives would bring issues of concern to the company's attention in a 'modern' way, providing in so doing an example of responsible leadership to the wider community. They functioned, Dibwe dia Mwembu argues, less as community representatives than as informants about it, identifying problems that might otherwise create conflict. ${ }^{51}$ In 1958, the company explained that the council's role was to ensure contact between the employers and its indigenous personnel and to give the latter the opportunity to make their wishes known, but equally 'to be kept informed of the measures which contribute to them'. In this respect, however, it complained that 'advisers only very imperfectly fulfil their information role with their constituents and workers have often complained about [this failure]. A long educational effort will still be required in this area' 52

The CIE representatives articulated a wide range of both workplace and community grievances: poor treatment by Europeans, complaints over promotions, qualifications, pensions and payments, but also the electrification of workplace housing, the sale of beer and the provision of health care and drinking water. ${ }^{53}$ From the 1958 and 1959 UMHK reports, we can identify broad areas of concern - presented here in summary - without being able to accurately rank their significance to the CIE members who raised them:

- Housing: provision of materials to help UMHK employees build their own homes; electric lighting needed; interior doors to be installed in houses; the size and position of windows in new houses; household water supply.

- Transport: the need for a bus service to and from work; long queues at railway stations; provision of vehicles to move furniture and luggage.

50 Personal correspondence with Donatien Dibwe dia Mwembu, March 2020.

51 Dibwe dia Mwembu, Histoire des Conditions de Vie, p. 54.

52 UMHKA, 658, MOI Annual Report 1958, p. 47.

53 Dibwe dia Mwembu, Histoire des Conditions de Vie, p. 54. 
- Financial: demands for a pay rise; compulsory monthly savings scheme; pensions; salary payment dates.

- Township: electric lighting needed in streets and houses; the sale of more fish and meat in the market; the right of workers' wives to sell goods in markets; food distribution issues; security; the quality and cleanliness of facilities including water taps, toilets and roads; demands for public wastebins.

- Health, education and social welfare: insufficient local schools; transport of pupils to schools; provision of midwives; transport of pregnant women to hospitals.

- Workplace conditions: modification of working hours; provision of specialised clothing; complaints against Europeans still insulting African workers; sirens to ensure workers are on time; disciplinary issues; Africanisation of senior positions; leave problems.

It is also not possible to definitively assess how UMHK responded to all these complaints. In 1958, for example, the company reported it was expanding electric lighting and increasing the number and size of township markets, particularly as it moved more senior workers from in-kind to fully cash wages. Certainly, some areas of provision recalled by interviewees today as being among the best aspects of UMHK township life, for example cleaning and refuse collection services, were the subject of CIE complaints.

Meanwhile, and in sharp contrast to Northern Rhodesia, industrial peace reigned supreme in the Katangese mines: no significant industrial action occurred between the 1941 strike and independence. Whether this reflected the effectiveness of CIE consultation, the company's authoritarian control of mine townships and workplaces, or the relative contentment of mineworkers and their families with UMHK's increasing provision of housing and social services, it is difficult to gauge. It is clear, nonetheless, that the company was continually anxious: about whether CIE representatives were sufficiently advanced to play the educational and leadership role expected of them; about the cost of providing housing and social services to its expanding township population, particularly its children; and about its ability to exclude from its ordered camps the 'political difficulties' arising in Katanga and Congo as a whole.

The 'failure' of wartime unrest in Katanga and Congo to coalesce into a wider mass nationalist movement is something that historians 
have sought to explain. In 1976 Bogumil Jewsiewicki characterised this as a failure of leadership:

In the post-war period, under the 'preventive' legislation put in place in 1946, the black proletariat came under the tutelage of European trade unions, advisers, the administration and the missions. It dissolved in the mass of newcomers (in the prosperity of the early 1950s) [and] lost solidarity in the face of the rise of politicized ethnicity.... In the absence of its own social ideology, and of a group of leaders capable of waging a political and social struggle at the same time, African trade unionism was aborted. The black intelligentsia (the évolué) stood aside and weighed the advantages of collaboration against those of independence. ${ }^{54}$

It is unsurprising that wartime labour militancy, reflecting as it did acutely exploitative conditions, was not maintained during a post-war boom that enabled significant improvements in wages and social benefits. Certainly, the Belgian Congo's distinct failure to make political reforms akin to those in French and British-ruled Africa, and the ban on territory-wide political parties maintained until 1957, channelled Congolese frustrations and aspirations into increasingly politicised ethnic associations. ${ }^{55}$ The perceived failure of African leadership and the attempts of évolués to advance their own position within colonial society does not, however, make Congo unusual. Indeed, Northern Rhodesia's early native associations/welfare societies were just as elitist as their Congolese counterparts, adopting a more 'national' focus only when their sectional aspirations were threatened by the establishment of the Central African Federation. There was no natural journey towards nationalist unity among Northern Rhodesia's disparate political and social movements, representing as they did distinct social, economic and cultural interests.

\section{Haut-Katanga's Centres Extra-Coutumiers}

While UMHK and other companies closely policed their workers through mechanisms such as the CIEs, the Centres Extra-Coutumiers

54 Bogumil Jewsiewicki, 'La Contestation Sociale et la Naissance du Prolétariat au Zaïre au Cours de la Première Moitié du XXe Siècle', Canadian Journal of African Studies, 10, 1 (1976), pp. 47-71, p. 69.

55 Lemarchand, Political Awakening, pp. 192-7; Young, Politics in the Congo, pp. 232-72. 
were the subject of greater official anxiety. The Elisabethville CEC was established by decree in 1932 to house the growing African population, away from European residents. By the early 1950s, the area, by then known as 'Kenya', was home to c.20,000 or 57 per cent of Elisabethville's African population and was the subject of a major CEPSI study published in 1951. Ferdinand Grévisse, the former colonial administrator, painted a disparaging picture of this rapidly growing African area of a city that was otherwise the heart of the white Katangese settler community. ${ }^{56}$ Far from responding positively to the challenges of wage employment and modern urban life, the CEC's Africans had lost all the qualities of their rural communities and gained none of the advances of Western culture. They were, Grévisse asserted repeatedly, dull-minded wage slaves who lacked initiative and imagination, whose 'sense of responsibility is as obsolete as their moral sense'. ${ }^{57}$

Grévisse argued that urban associational authority could not replicate that in rural areas, since 'African intermediaries ceased to be emanations of the customary milieu' and could not then be an effective means of understanding or controlling 'the indigenous masses' ${ }^{58} \mathrm{In}$ line with social scientific thinking, Grévisse believed CEC residents were experiencing a transitional existence influenced by both rural/ tribal and urban/modern 'civilisations': 'the social body of the CEC is going through a period of transition. European civilization ... diffuses a set of cultural values too high, too strange and, above all, presented in a manner insufficiently positive to be immediately assimilable and transposable to daily life'. ${ }^{59}$ Unlike Epstein and his RLI colleagues, however, he had virtually nothing good to say about this process:

They [CEC residents] all maintain intense relations with their customary society, receive visits, accommodate nephews wishing to pursue studies, even if it means raising their little daughters in the village. They indulge in abundant exchanges of written or oral messages, gifts in kind and in money. Through all their sensitive, affective, intellectual ... fibres, they remain in contact with their native environment. ${ }^{60}$

56 Ferdinand Grévisse,Le Centre Extra-Coutumier D'Elisabethville: Quelques Aspects de la Politique Indigène du Haut-Katanga Industriel (CEPSI: Brussels, 1951).

57 Grévisse, Le Centre Extra-Coutumier, p. 281.

58 Grévisse, Le Centre Extra-Coutumier, p. 305.

59 Grévisse, Le Centre Extra-Coutumier, p. 379.

60 Grévisse, Le Centre Extra-Coutumier, p. 372. 
Yet the same CEC population, Grévisse noted, rode bicycles and took taxis, dressed up on a Sunday and attended cabarets, cinema, jazz concerts and sporting events. They sought out decent accommodation and bought European-style furniture for their new houses. These were not, for Grévisse, signs of a positive adjustment to European civilisation but instead disturbing evidence of a premature and crude materialism among an uneducated urban mass with worrying political aspirations: 'the natives are interested in the vague and dangerous abstractions which are called freedom, independence, democracy and especially race, even before they have been able to become aware of their immediate environment'. ${ }^{61}$

The solution to such problems was the nurturing of the advanced, intellectual évolués; Grévisse identified c.500-600 CEC residents with reasonable education and French language, but fewer than a hundred 'who really aim to maintain their knowledge and learn more'. ${ }^{62} \mathrm{He}$ praised the work of institutions such as the Cercle Saint-Benoit, founded by de Hemptinne's Saint Jean Mission in 1931, in providing 'an environment that is agreeable and conducive to the promotion of the moral and intellectual development of their members ... and an artistic, literary and cultural character'. ${ }^{63}$ The newspaper L'Echo $d u$ Katanga provided another outlet for elite African expressions of advancement within the considerable constraints of paternalistic colonialism. ${ }^{64}$ While the leadership of évolués in the Cercle was praised, Grévisse did not envisage that their resultant understanding of 'social questions, economic questions, literary and even scientific' issues would translate into effective political leadership to the wider CEC populace any time soon. ${ }^{65}$ Nonetheless:

Detached from the traditional environment ... the évolués crystallize no longer around their small social structure of yesteryear - the clan - but around broader conceptions, tribal or regional. ... men seek to federate in one form or another. All these steps are the prelude .... to the birth of Bantu nationalism. ${ }^{66}$

61 Grévisse, Le Centre Extra-Coutumier, p. 27.

62 Grévisse, Le Centre Extra-Coutumier, p. 393.

63 Grévisse, Le Centre Extra-Coutumier, p. 314.

64 Fetter, 'Lulabourg Revolt', p. 271.

65 Grévisse, Le Centre Extra-Coutumier, p. 362.

66 Grévisse, Le Centre Extra-Coutumier, p. 397. 
While Grévisse's relatively early study says more about his racialised worldview than about African society in Elisabethville, it reflects a wider pessimism among Belgian administrators regarding urban Africans that informed a reluctance to grant them a meaningful administrative role. An advisory body for the CEC, the 'Centre Council', had been established by statute: it included twelve African representatives and a 'Chef de Centre', a position to be held by an African who would advise the colonial administration. ${ }^{67}$ In practice, however, this pivotal position was vacant from 1936 and its role was effectively occupied by a senior Belgian colonial official. The deputy Chef de Centre position, also long vacant, was eventually filled in 1955 . However, as Caprasse documents, the African appointee, while being trained in aspects of colonial administration, lacked meaningful authority: 'This situation annoyed the opinion (especially of the 'educated' elite) who came to wonder what such a function was useful for. In addition, it left the deputy centre chief with a painful feeling of helplessness' ${ }^{68}$ The wider council was characteristically composed of the CEC's educated elite: its members were mostly clerks and tutors of various kinds who, Caprasse found in the late 1950s, were also involved in the leadership of both cultural cercles and tribal associations (see below). However, these councillors were unwilling or unable to advance the grievances and aspirations of the wider CEC population for fear of being seen as radicals, and the council was regarded as an ineffective consultative body. ${ }^{69}$

Meanwhile, évolués continued to experience daily discrimination at the hands of European settlers. Participation in educational and cultural activities such as the cercles raised the possibility of political change but did nothing to deliver it. Many évolués perceived themselves, as Grévisse suggested, as caught between an indigenous majority they regarded as primitive and a European authority that refused to recognise them as equal. ${ }^{70}$ 'Participatory' institutions such as the CEC council left meaningful authority in the hands of Europeans, whose

67 Grévisse, Le Centre Extra-Coutumier, p. 28.

68 Caprasse, Leaders Africains en Milieu Urbain, pp. 96-7.

69 Caprasse, Leaders Africains en Milieu Urbain, pp. 105-13.

70 See interview with Paul Lomani Tshibamba in Jeff Van Bilsen, Congo, 1945-1965: La Fin d'une Colonie (Brussels: CRISP, 1994), quoted in Dibwe dia Mwembu, Histoire des Conditions de Vie, p. 53. 
persistent approach to the ceding of real power to Africans can be summarised as 'not yet'.

\section{Race and Respectability on the Northern Rhodesian Copperbelt, 1957-1960}

Despite their contrasting approaches to African urban organisation, the underlying thinking of British and Belgian authorities had much in common. Across the Copperbelt, initiatives promoting 'partnership' between Europeans and Africans provided institutional roles to advanced or elite Africans, considered more modern and/or civilised and able thereby to provide leadership to the wider urban African population. The integration of this group into the consultative bureaucracy of the local state and the mining industry was envisaged as a break on the radical or 'unrealistic' demands of the African masses and as a mechanism through which this new African elite could educate this latter group.

Mission-educated Northern Rhodesian Africans, literate in English and occupying an increasing number of clerical and educational roles in Copperbelt society, played a major role in shaping political activism. ${ }^{71}$ Most such 'advanced' Northern Rhodesian urban Africans churchmen, head teachers and local government officials - worked outside the mine companies. Seeking to convert their educational and employment achievements into social and political advancement, they had created Welfare Associations in most towns in the 1930s and early 1940s. These established a Federation of African Welfare Societies in 1946, first led by Luanshya headteacher Dauti Yamba. ${ }^{72}$ It made strenuous attempts to position itself as 'non-political' but provided a training ground for leaders of the Northern Rhodesia African National Congress (NRANC), established in 1951.

While in Katanga the education and advancement of évolués was nurtured, particularly by Catholic bodies such as the Cercle SaintBenoît, British colonial officials were generally dismissive of educated

71 Roberts, History of Zambia, pp. 196-201; Hall, Zambia 1890-1964, pp. 58-70.

72 Mwelwa C. Musambachime, 'Dauti Yamba's Contribution to the Rise and Growth of Nationalism in Zambia, 1941-1964', African Affairs, 90, 359 (1991), pp. 259-81. 
Africans, as this 1951 analysis by a Copperbelt government official shows:

Political ambition, coupled with an awareness of their superiority, has developed in them a disagreeable 'hubris' derived from an exaggerated belief in their own capacity, and this in its turn has rendered them both sensitive and resentful of their treatment by the European community.... the intelligentsia have come also to believe themselves justified in ... intemperate demands for the immediate ... enhancement of their own political and economic position. ${ }^{73}$

The comparative disregard of Northern Rhodesia's colonial leaders in nurturing moderate African elite opinion, and the settler campaign to convert the CAF into a segregated dominion, fuelled a turn towards mass campaigning in the mid-1950s, led by the NRANC's Harry Nkumbula, schoolteacher and former Secretary of the Mufulira Welfare Association. In the Copperbelt, racial discrimination manifested itself in the continuing colour bar in mines and other workplaces, and the 'petty apartheid' restricting African patronage of bars, restaurants and shops. The NRANC launched boycott campaigns against butchers in Lusaka and its leaders, Nkumbula and Kenneth Kaunda, were jailed in 1955. Growing racial tension and the more militant approach of Kaunda's United National Independence Party (UNIP), which split from the NRANC in 1958-9, culminated in the killing by UNIP activists of a white resident of Ndola, Lilian Burton, in April $1960 .^{74}$

Amidst this growing tension, a Race Relations Ordinance was passed in 1957, one measure of which was to establish local Race Relations Committees (RRCs) to promote good racial relations and to desegregate public facilities. They equally served as a vehicle for moderate African elites to demonstrate their credibility as responsible political leaders and to advance their demands for political progress. However, in Mufulira the new Race Relations and Conciliation Committee, meeting for the first time in December 1957, found its hands tied regarding the Mufulira Copper Mines' Recreation Club. Although

73 NAZ, WP 1/11/2, African Social and Political Development in Urban Areas, 1951 Report.

74 Walima Kalusa, 'The Killing of Lilian Margaret Burton and Black and White Nationalisms in Northern Rhodesia (Zambia) in the 1960s', Journal of Southern African Studies, 37, 1 (2011), pp. 63-77. 
this club explicitly refused membership to Africans, as a mine company facility 'the Club was not an institute over which the Committee had any jurisdiction or powers' ${ }^{75}$ The committee sought to promote mutual understanding by public education: it compiled a multi-racial list of 'lecturers' able to share knowledge on subjects including: European marriage customs; road safety; African medicine; African urban marriage problems; the effect of European culture on African traditional manners and customs; how Europeans bring up their children; African female education; juvenile delinquency; African labour problems; and African family budgets. ${ }^{76}$ In many of its discussions on racial exclusion from restaurants and hotel bars, African members expressed frustration at the stereotypes of lower-class Africans that informed these policies and compared Northern Rhodesia unfavourably with neighbouring Congo:

Mr Mukuka said the well-dressed African would not enter many of these establishments because of the behaviour of the Europeans. Bars and hotels in the Congo were inter-racial and there was no trouble, and he did not see why the same could not be done here. As to the objection that Africans were dirty, firstly this was not true of all Africans and secondly, he had observed some European mechanics and artisans coming straight from work to a café or bar in dirty and greasy overalls. ${ }^{77}$

As Mukuka's comment indicates, the displacement of racial divisions to those of class and 'civilisation' suffused these committees' discussions. At the Ndola RRC, the manager of the First Permanent Building Society denied that it operated a colour bar and stressed that a tradesmen's entrance was in use at the rear of the building: 'He thought that the main distinction would be dress: a decently dressed person would obviously use the lift, and a person not suitably dressed would use the stairs' ${ }^{78}$ Likewise, the Northern Rhodesian Hotels Association agreed in January 1957 that '[n]on-Europeans who were properly dressed, knew how to behave, who could afford to pay the bill and wanted to

75 NAZ, WP 1/5/18, Mufulira Race Relations and Conciliation Committee, 1957-62, Minutes of First Meeting, 18 December 1957.

76 NAZ, WP 1/5/18, Mufulira Race Relations Committee, 1957-62, Minutes of Fourth Meeting, 21 March 1958.

77 NAZ, WP 1/5/18, Mufulira Race Relations Committee, 1957-62, Minutes of Third Meeting, 10 March 1958.

78 NAZ, WP 1/5/20, Ndola Race Relations Committee, 1958-62, Minutes of Fourth Meeting, 25 March 1958. 
use the hotels for legitimate purposes and not for political ends would be normally accepted'. ${ }^{79}$ African members accepted the right of establishments to exclude undesirable customers, but one argued: 'Many Africans could well afford, and had the wish, to purchase a decent meal properly served. African tea rooms were very crude, and a welleducated and well-dressed African wanted something better'. ${ }^{80}$ A subsequent Race Relations Ordinance, passed in September 1960, legally desegregated hotels, restaurants and cinemas. ${ }^{81}$

While late colonial advancement depended on the assumed ability of this elite indigenous leadership to moderate the political demands of the wider African population, this was undermined in both Congo/ Katanga and Northern Rhodesia by different restrictions on the advancement of elites. Évolués in Haut-Katanga, mission-educated and attaining skilled jobs, were frustrated by the lack of political reform despite demonstrating their advanced credentials in the cercles' intellectual and cultural activities and by their adoption of 'European' dress and language. Meanwhile, the continuing colour bar in the Northern Rhodesian mines reinforced a tendency towards radical nationalism and political participation, both among skilled African mineworkers and hitherto moderate intellectuals. The ability of elite Africans to advance their own position through a liberal discourse of respectability and civilisation was, in both colonies, giving way to a recognition that this could only be achieved by the transfer of political power.

\section{Copperbelt Political Identities on the Road to Independence}

As has been noted, social scientific analysis of the Central African Copperbelt generally assumed that, over time, ethnic identities associated with migrants' rural areas of origin would be displaced by 'modern' identities reflecting urban residence and changed material circumstances. Modern forms of organisation would displace the earlier forms of combination practised by new urban migrants, most

79 NAZ, WP 1/5/20, Ndola Race Relations Committee, 1958-62, Minutes of Sixth Meeting, 12 July 1958.

80 NAZ, WP 1/5/20, Ndola Race Relations Committee, 1958-62, Minutes of Seventh Meeting, 7 October 1958.

81 NAZ, WP 1/5/20, Ndola Race Relations Committee, 1958-62, Annual Report 1960. 
notably 'tribal' associations. On both sides of the border, as elsewhere in towns across Africa, self-help networks were established to assist new arrivals to town. While older interviewees recall being helped by family and kinship networks to find work and housing, or manage financial and family crises, these support networks evolved across the Copperbelt into more established mutual aid associations organised along ethnic lines. Nguni Tamarikzika's early years in Mufulira in the early 1960 s were, for example, eased by 'a Nsenga group so that if there was any problem, suffering or death then all the Nsenga people would come together and assist in that area' ${ }^{82}$ Integrationist policies ostensibly militated against overtly ethnic social or workplace segregation: workers were housed in multi-ethnic areas and worked in multi-ethnic and multi-racial groups. The AMWU and the CIE, in their different ways, were both organised across ethnic lines. 'Tribal' identity was, however, officially preserved in ways deemed appropriate for the colonial social order. Tours by African chiefs to visit their urban 'subjects' continued to be organised until the early 1960s: in 1960, for instance, four such visits took place to Kitwe. ${ }^{83}$

Unlike religious sects and more overtly political organisations, urban tribal associations were not a primary focus of either political surveillance or social scientific attention, based as they were on 'premodern' associational identities that were surely in decline. Yet by the late 1950s it was clear that the CEC's tribal associations, established initially as self-help and 'cultural' groups, were becoming increasingly politicised and combining into federations reflecting larger-scale ethno-regional migrant identities. Caprasse, writing shortly before Congo's independence, offers a compelling snapshot of the leadership of these associations, particularly those claiming to represent the largest ethnic groups: the Luba Kasai (28.6 per cent of the Elisabethville CEC's population); the Luba Katanga (18.1 per cent), the Lunda (6.3 per cent), the Bemba (4.3 per cent) and so on. ${ }^{84}$ These associations were often poorly organised, with irregular meetings and low official membership, but their 'spontaneous' character and lack of European involvement enabled them to act relatively autonomously. Caprasse demonstrated that the insecure conditions and precarious

82 Interview, Nguni Tamarikzika, Mufulira, 3 July 2018.

83 NAZ, WP/1/2/64, Special Commissioner for Western Province Reports on Copperbelt, 1959-60, Annual Report on African Affairs, Kitwe, 1960.

84 Caprasse, Leaders Africains en Milieu Urbain, pp. 23-4. 
employment of many urban migrants (see Chapter 2) meant that existing forms of solidarity modelled on 'the customary environment' were being 'adapted to the conditions of urban life', and 'modernized ... to current living conditions'. ${ }^{85}$ Continued ethnic identification and solidarity could be understood as an implicit protest against the harsh, impersonalised nature of urban life, fuelling a desire to preserve the supposedly communitarian values of the village.

Ethnic association leadership involved, Caprasse found, a mix of younger, primary-school-educated men (one rung lower on the social ladder than the most educated évolués) able to organise the bureaucratic paraphernalia of a recognisably modern organisation, alongside elders whose rural upbringing made them custodians of tribal culture and law, particularly where - as in the case of the Lunda association - key individuals were designated by the Lunda king, the Mwaant Yaav, to regulate conflicts among his urban 'subjects'. ${ }^{86}$ As political opportunities and threats emerged with the largely unheralded approach of Congolese independence, these organisations adopted apparently contrasting political aims: 'there are leaders who speak of resuscitating ancient kingdoms which have disappeared: on the other hand, other leaders have a realism which aims at immediate effectiveness: they seek to obtain for themselves and the members of their group certain positions in the current administrative system, ${ }^{87}$ For Caprasse this contrast could be explained, characteristically for his generation of Copperbelt social scientists, by the contradictions inherent in transition:

These tensions within associations are an indication that a society in transition guards the vestiges of its old values and social structures which collide with the new ones. On the one hand, age still confers a certain authority, while, on the other hand, change grants authority to leaders whose status and roles are new. ${ }^{88}$

Caprasse, seeking to counterpose the vertical appeal of tribal associations to the non-ethnic elite identity of the CEC's cercles, found, however, that even the latter were engaging in ethnically based

\footnotetext{
85 Caprasse, Leaders Africains en Milieu Urbain, pp. 29-30.

86 Caprasse, Leaders Africains en Milieu Urbain, p. 52.

87 Caprasse, Leaders Africains en Milieu Urbain, p. 34.

88 Caprasse, Leaders Africains en Milieu Urbain, p. 56.
} 
competition for leadership positions. ${ }^{89}$ Ethnic association was proving not to be a declining hangover of the rural-urban transition but rather a potent form of urban political mobilisation, whether on its own or combined with ostensibly 'modern' bases of belonging, along class or racial lines. This debate was played out in the pages of the new journal Katanga in which évolués of different ethnic background virulently attacked each other's visions of the country's national future. ${ }^{90}$

These very modern ethnic associations proved central to the political conflict that unfolded in Haut-Katanga in the run-up to independence. The 1957 election in Elisabethville of four bourgmestres (local mayors) of non-Katangese ethnicity suggested that future political authority would rest in the hands of mainly Kasian 'migrants'. ${ }^{91}$ This prospect was met with alarm by 'autochthonous' Katangese groups and prompted large ethnic federations, for example Gassomel (the Groupement des associations de l'empire lunda), to establish political parties including the Confédération des associations tribales $d u$ Katanga (Conakat). Conakat, fearing a post-independence loss of Katangese autonomy, bitterly opposed what it characterised as foreign domination by a Kasaian political elite allied with Patrice Lumumba's Mouvement Nationale Congolaise (MNC); Conakat leaders attacked local Kasaian leaders in an openly xenophobic way. ${ }^{92}$ In asserting their nationalist project, Conakat leaders harked back to a supposed golden age of pre-colonial Katanga in which its great kingdoms had become wealthy and powerful through regional trading networks in commodities including minerals: the copper croissette served as a national symbol on the flag and in the anthem of the Katangese state, which seceded from Congo days after independence in June $1960 .{ }^{93}$

89 Politics in Congo, pp. 293-4.

90 Omasombo Tshonda et al., Katanga Vol. 1, pp. 233-4.

91 It should be stressed that all urban residents were 'migrants' in the sense that all had their origin in rural areas outside the mining towns, including those from rural Katanga such as the Lunda and Bemba. The political distinction that was drawn was between these self-declared 'autochthonous' Katangese groups and those from outside Katanga, particularly the Kasai Luba, even those born in Katangese towns to migrant parents.

92 Lemarchand, Political Awakening in the Congo, pp. 238-9.

93 Godefroid Munongo, Comment est né le Nationalism Katangais, Elisabethville, 16 June 1962 (mimeo), cited in René Lemarchand, 'Katanga: background to secession', unpublished ms (1963); Erik Kennes and Miles Larmer, The 
The enabling of the Katangese secession by UMHK, by the redirecting of tax payments to the illegal state, sat uneasily with the company's attempts to preserve its mine townships as apolitical enclaves, unaffected by the political conflicts in which it was a key actor. ${ }^{94}$ By March 1960 its local management recognised it could not keep these events outside its gates, as two of its workers were killed and many injured in the ethno-political violence during pre-independence elections. ${ }^{95}$ There was, meanwhile, a politicisation of the demands advanced in the CIE: alongside familiar complaints about working hours, housing, township services, family allocations and the distribution of food, CIE representatives now demanded the Africanisation of senior positions; criticised racialised policing; and complained that the holding of political meetings required company authorisation. In relation to the Councils themselves, representatives requested an extension of their mandate from two to five years and that they be provided with the minutes of CIE meetings. Company officials commented on the changing profile of CIE representatives:

these councils, originally composed of old workers of high seniority, known in our cités as the village notables [have been replaced by] more young skilled workers, young clerks, young tutors, etc. ... as if, in the spirit of their mandates, such representatives were better able to present and defend their wishes. It should be added that tribalism this year, more than ever, dominates relations and directs the choice of all workers in this field. The present circumstances being what they are it is difficult to demand of an African that he is not influenced, consciously or not, by clan ties. ${ }^{96}$

Of course, many European observers understood such manifestations of ethnically based political mobilisation to be evidence of a failed or incomplete transition to modern identity and consciousness, but by 1960 it was no longer possible to argue that more time would be needed for African societies or leaders to complete an envisioned transition to the 'right' kind of African modernity.

In Northern Rhodesia, in contrast, Copperbelt political activism in the early 1960s, leading to Zambia's later independence in 1964, overtly rejected both ethnically based politics and moderate elite co-operation in

Katangese Gendarmes and War in Central Africa: Fighting Their Way Home (Bloomington: Indiana University Press, 2016), pp. 36-7.

95 UMHKA, 658, MOI Annual Report 1960. ${ }^{96}$ Ibid. 
favour of the militant but non-racial leadership of UNIP. The Copperbelt, and Bemba-speaking areas of northern Zambia linked to it by migration, saw in 1960-1 the greatest level of anti-colonial mass mobilisation and direct action against state property, which took its nominative inspiration - the 'Cha Cha Cha' rebellion - from the celebration of Congolese independence. ${ }^{97}$ Some interviewees recall their involvement in this anti-colonial activism as arising from personal experiences of racial discrimination. ${ }^{98}$ John Mule spent five months in prison for his UNIP activities. ${ }^{99}$ Elizabeth Malokoleta, UNIP Women's Regional Secretary in Kitwe while still a teenager, explains: 'We wanted to rule ourselves. Self-governance. We felt limited. We wanted schools and secondaries ... mostly white people went to school. When we started fighting for independence is when they started taking us'. ${ }^{100}$

This grassroots activism, which was central to the achievement of self-government, was, however, regarded uneasily by the UNIP leadership, which sought to benefit from its threat potential while retaining control of African political organisation. ${ }^{101}$ Central to these efforts was the use of political violence against its rivals in the NRANC, particularly in the latter's Copperbelt stronghold of Mufulira. Many interviews recall this as a dangerous period in which mainly Bembaspeaking UNIP supporters were deployed against NRANC members from southern and western Zambia, and vice versa. ${ }^{102}$

In the run-up to Zambian independence, AMWU was an unmistakably politicised body: branch meetings asserted that, in the new political dispensation, African mineworkers could ensure their equality and dignity at work under the protection of their new black government. In Luanshya in December 1962, a crowd of 6,000 heard national and branch leaders declare:

- Europeans who accept Black Government have nothing to fear

- If a European assaults an African, the African should 'hit the European back as hard as he could' and fight it out to the end Jazz group.

98

100

101

102

'Indépendance Cha Cha' was a hit song of 1960 by Joseph Kabasele's African

Interview, B. M. Chama, Mufulira, 6 July 2018. $\quad 99$ John Mule interview.

Interview, Elizabeth Malokoleta, Mufulira, 2 August 2018.

Larmer, Rethinking African Politics, pp. 40-3.

Mufulira Interviews: Levy Chushi; Emelia Banda; and Leonard Nkhuwa, 17 July 2018. See also Giacomo Macola, Liberal Nationalism in Central Africa (New York: Palgrave, 2010). 
- Africans must stop carrying food bags for European employees

- African mine employees must discontinue the so-called respectful approach to European mining employees - they must only say 'Ya' and no longer 'Ya bwana'. ${ }^{103}$

The challenges facing AMWU's leadership were meanwhile neatly summarised in a speech by Minister of Labour and Mines John Roberts to its 1960 conference:

Foreign investors are hard-boiled people who demand absolute proof of a country's good intentions before starting up new industries which we need if we are to prosper. ... one of the main factors to be considered is whether a country has a responsible and contented labour force. ... enlightened employers of today, like the mining companies ... go to considerable expense to provide all kinds of facilities for the benefit of their workers and their dependents.... These facilities go a long way towards satisfying the material and physical needs of urbanised Africans, but what about their spiritual needs? ... the vast majority of Africans on the Copperbelt are still not fully de-tribalised. ... In the village the spiritual needs of Africans are satisfied by their Chiefs, village headmen and tribal elders, but this system ... breaks down in urban areas. ... it is here that a sound trade union can contribute so much to the welfare of their members. The responsibility resting on trade union leaders is considerable... There are also many politicians who purely for their own ends would like to get a foothold in your organisation.... My advice to you is to resist this with all your might. A trade union with political aims weakens itself. ${ }^{104}$

While the Minister's warning against 'politicisation' was designed to moderate AMWU's political mobilisation, it was nonetheless prescient. Conflict emerged in the early 1960s between UNIP and AMWU as the former positioned itself as the party of workers and peasants and asserted the need for trade union loyalty and subordination to it. ${ }^{105}$ Most AMWU leaders strongly supported the more radical UNIP and ousted their moderate pro-NRANC president Lawrence Katilungu. They, however, equally sought to ensure they were not subject to

103 NAZ, LSS 1/26/33, Luanshya AMWU, 1949-65, Record Note, AMWU Public Meeting, 22 December 1962.

104 NAZ, LSS 1/26/184, N Rhodesia AMWTU, 1960-4, Minister's Speech, 26 May 1960.

105 Larmer, Mineworkers in Zambia, pp. 38-40. 
UNIP control, for example by rejecting its calls to organise a general strike in support of its independence demands in January 1962. ${ }^{106}$ Four months later, AMWU leaders were persuaded by UNIP to call off strike action because it might adversely affect planned elections. In the run-up to independence, UNIP fostered a United Mineworkers' Union (UMU) as a rival to AMWU, but this proved unsuccessful. ${ }^{107}$ The RLI's Peter Harries-Jones captured the intensity of the competition between AMWU and UNIP for the political loyalty of Luanshya's mineworkers during this period: local UNIP activists, making use of their kinship networks, sought to mobilise these communities over a range of social concerns and grievances, from literacy to funeral costs. To do so, however, necessarily involved party control over and repression of independent associations, of which AMWU was by far the most significant. ${ }^{108}$

Demands by AMWU for representation at pre-independence talks between the government, led from January 1964 by Prime Minister Kenneth Kaunda, and the mine companies concerning the industry's future, were rejected. Underlying such demands was the union's assertion of its right to represent the mining community in the emerging post-colonial political dispensation. In this context it used an unmistakably modernist discourse to pursue the 'advancement' of its members' living standards:

During the past thirty years the level of technological skill and ability of the African worker has greatly increased. Through African Advancement schemes individual workers have accepted higher levels of responsibility.... The Union regrets that the advancement of the thinking processes of the Mining Companies' policy makers has not kept pace with the advancement of their African employees. ... It is however high time that the mining companies recognised that they are faced no longer with the inexperienced people they first dealt with here on the Copperbelt. ${ }^{109}$

106 Meebelo, African Proletarians and Colonial Capitalism, pp. 453-78.

107 Northern News, 8 October 1964; Bates, Unions, Parties, and Political Development, pp. 149-51. The local manifestation of this struggle for union control is well documented in NAZ, LSS 1/26/33, Luanshya AMWU,1949-65, various documents.

108 Peter Harries-Jones, Freedom and Labour: Mobilization and Political Control on the Zambian Copperbelt (Oxford: Basil Blackwell, 1975), passim.

109 NAZ, LSS 1/26/184, N Rhodesia AMWTU, 1960-4, Notes of AMWU for negotiations, n.d. but February 1964. 


\section{Conclusion}

The growing urban communities of the Central African Copperbelt faced a wide range of difficulties and injustices as they sought to assert themselves in a rapidly changing post-World War Two context. Low wages, racial inequality and the wider limits placed on individual and societal ambitions led many to protest and combine to overcome injustice and discrimination and find a collective political voice. These efforts were resisted by colonial and company authorities, but also channelled into acceptably 'modern' forms of associational activity in which advanced Africans were expected to articulate community grievances within a participatory framework that simultaneously restrained the 'unrealistic' or 'premature' demands of the wider African population. The different approaches adopted in HautKatanga and Northern Rhodesia's mining industries produced contrasting outcomes. The AMWU, overcoming divisions within the mine workforce, emerged as a powerful political actor in Northern Rhodesia's mine townships by linking 'irresponsible' community activism with claims for improved wages and conditions that would enable mineworkers and their families to live respectable, 'civilised' lives. The proactive concession of improved wages and conditions to UMHK's workers, along with the incorporation of worker representation into the CIEs, delivered industrial peace. Neither mechanism, however, provided a sustainable resolution to underlying demands that African societies should exercise control of their own communities, extractive resources and ultimately nations.

Outside the mine townships, educated and more successful Africans both internalised and challenged the notion that 'advancement' meant progress along European lines. Participation in welfare associations, race relations committees and elite cultural groups provided opportunities for self-improvement and self-expression, but also necessitated distancing oneself from the wider urban community and offered meagre political and economic rewards. Meaningful political change required new forms of association and, in the global context of decolonisation into independent nation-states, the establishment of selfconsciously nationalist political organisations. Nationalist parties and the struggle for independence dominated the political narrative of the late 1950s and early 1960s, but this did not replace the associational expression of grievance and aspiration by trade unions, ethnic 
associations and other combinations in which diverse sections of the community engaged to improve their lot and to collectively express their distinct social identities. These collectives provided training grounds for party political activists. They often complemented and overlapped in their membership's concerns with those of nationalist parties, but also clashed with the latter's desire to monopolise political space and control the agenda.

The ways that these rapid, dislocating changes were understood and represented - by companies and colonists, social scientists and activists themselves - were marked by modernist conceptualisations of political and social change. These often provided a distorted understanding of a messy reality, in which multiple and often contradictory forms of identity and association - class, ethnicity, race and nation - combined in unpredictable ways that, while facilitating the political transition from colony to nation-state, did nothing to resolve those contradictions and little to address the inequalities and injustices that fuelled them. 